\title{
KECERNAAN BAHAN ORGANIK, SERAT KASAR DAN LEMAK KASAR PAKAN AYAM PEDAGING YANG DIBERI TEPUNG LIMBAH LABU KUNING (Cucurbita moschata)
}

\author{
Andre F. Moningkey, Fenny R. Wolayan*, Cathrien A. Rahasia, Mursye N. Regar.
}

Fakultas Peternakan Universitas Sam Ratulangi Manado, 95115

\begin{abstract}
ABSTRAK
Suatu penelitian yang bertujuan untuk mengetahui nilai kecernaan pakan (bahan organik, serat kasar dan lemak kasar) yang diberi tepung limbah labu kuning (Cucurbita moschata). Penelitian ini dilakukan dengan menggunakan 20 ekor ayam pedaging unsexed, strain CP 707 berumur 5 minggu, dengan rataan berat badan \pm 1073 gram. Rancangan yang digunakan adalah Rancangan Acak Lengkap (RAL) dengan 4 perlakuan 5 ulangan. Hasil uji lanjut dengan uji beda nyata jujur (BNJ). Perlakuan yang diberikan adalah : $\mathrm{R}_{0}=100 \%$ pakan basal (RB) $+0 \%$ tepung limbah labu kuning (TLLK), $\mathrm{R}_{1}=95 \% \mathrm{RB}+5 \%$ TLLK, $\mathrm{R}_{2}=$ $90 \% \mathrm{RB}+10 \%$ TLLK, $\mathrm{R}_{3}=85 \% \mathrm{RB}+$ $15 \%$ TLLK. Hasil penelitian menunjukkan bahwa perlakuan memberikan pengaruh yang berbeda sangat nyata $(\mathrm{P}<0.01)$ terhadap kecernaan serat kasar dan tidak berpengaruh $(\mathrm{P}>0.05)$ terhadap nilai kecernaan bahan organik dan kecernaan lemak kasar. Hasil uji lanjut menunjukkan bahwa kecernaan serat kasar perlakuan R0 $(56,92 \%)$ berbeda nyata lebih rendah dibandingkan dengan perlakuan R1 $(63,10 \%), \mathrm{R} 2(67,71 \%)$ dan R3 $(66,30 \%)$ tetapi perlakuan R1, R2 dan R3 tidak berbeda. Berdasarkan hasil penelitian ini dapat disimpulkan bahwa tepung limbah labu kuning (Cucurbita moschata) dapat digunakan sebagai pengganti sebagian
\end{abstract}

*Kosepondensi (corresponding author)

Email: feny_wolayan@unsrat.ac.id pakan ayam pedaging sampai $15 \%$ dilihat dari kecernaan bahan organik, serat kasar dan lemak kasar.

Kata Kunci : Tepung limbah labu kuning, kecernaan, ayam pedaging

\section{ABSTRACT}

DIGESTIBILITY OF THE ORGANIC MATTER, CRUDE FIBER AND CRUDE FAT IN BROILERS RATION CONTAINING PUMPKIN WASTE MEAL (Cucurbita moschata). A research was done to determine the digestibility values of feed in term of organic matter, crude fiber and crude fat containing pumpkin waste meal (PWM) fed to broilers. The research was conducted by involving 20 unsexed broilers, strain CP 707 at 5 weeks old with an average body weight of $1073 \mathrm{~g}$. Experiment design of the Completely Randomized Designed (CRD) was applied with 4 treatments and 5 replications at each treatment. Honestly significant difference test (HSD) was used to define higher significant effects of the treatments. The treatments consist of $100 \%$ basal ration $(\mathrm{BR})+0 \% \mathrm{PWM}\left(\mathrm{R}_{0}\right), 95 \% \mathrm{BR}$ $+5 \%$ PWM $\left(\mathrm{R}_{1}\right), 90 \% \mathrm{BR}+10 \% \mathrm{PWM}$ $\left(\mathrm{R}_{2}\right)$ and $85 \% \mathrm{BR}+15 \% \mathrm{PWM}\left(\mathrm{R}_{3}\right)$. Results showed that digestibility of crude fiber was significantly affected by treatments $(\mathrm{P}<0.01)$, but digestibility values of organic matter and crude fat were not influenced by these treatments. The statistical test showed that the crude fiber digestibility of R0 (56.92\%) was lower than those of R1 (63.10\%), R2 (67.71\%) and R3 $(66.30 \%)$. Furthermore, there was no difference among digestibility values of 
$\mathrm{R} 1, \mathrm{R} 2$ and R3. Based on this research, it can be concluded that pumpkin waste meal could be utilized to replace some parts up to $15 \%$ in ration of broilers.

Keyword: Pumpkin waste meal, digestibility, broiler

\section{PENDAHULUAN}

Seiring dengan pertambahan populasi penduduk dan berkembangnya pengetahuan masyarakat akan manfaat gizi bagi pertumbuhan, kesehatan dan kecerdasan manusia, tuntutan kebutuhan akan sumber gizi hewanipun terus mengalami peningkatan dari tahun ke tahun. Kondisi tersebut, tentunya akan memicu pengembangan jenis - jenis ternak sumber daging sebagai substitutor kebutuhan daging masyarakat, salah satu jenis ternak yang mampu menyediakan kebutuhan daging secara cepat adalah ayam pedaging. Strain-strain baru ayam pedaging hasil pemuliabiakan yang dikembangkan oleh beberapa industri peternakan dengan capaian umur pemasaran relatif singkat (56 minggu). Hal tersebut menjadi pemicu usaha peternakan ayam pedaging di Indonesia pada umumnya dan Sulawesi Utara pada khususnya berkembang sangat pesat, sampai sekarang ini. Pakan merupakan komponen terbesar dari total biaya produksi yaitu mencapai 60-70\%. Upaya yang bisa dilakukan untuk mengatasi masalah ketersediaan pakan tersebut salah satunya adalah dengan memanfaatkan bahan pakan alternatif yang bisa dijadikan sebagai bahan pakan ternak unggas.

Limbah sebagai salah satu bahan pakan alternatif merupakan solusi dalam meningkatkan ketersediaan bahan baku penyusun pakan. Limbah yang dimanfaatkan sebagai bahan baku pakan dapat berasal dari bagian tanaman atau hewan yang dijadikan sebagai sumber protein, energi, vitamin dan mineral. Salah satu limbah yang dapat dimanfaatkan adalah limbah labu kuning. Limbah labu kuning adalah sisa pengolahan bahan pangan. Labu kuning merupakan tanaman musiman, sehingga produksi labu kuning akan sangat besar ketika musimnya tiba. Tingkat produksi labu kuning di Indonesia relatif tinggi, dan produksinya dari tahun ke tahun terus meningkat yaitu 428,197 ton (2011) dan meningkat 523,063 ton (2014) (Badan Pusat Statistik 2014).

Komposisi nutrien limbah labu kuning per $100 \mathrm{~g}$ antara lain; protein $23,14 \%$, lemak 14,59\%, serat kasar $17,48 \%$, kalsium $0,76 \%$, fosfor $0,75 \%$ dan energi bruto 3882,4 kcal (Komalig, et al., 2016). Kecernaan suatu bahan didefinisikan sebagai bagian yang tidak diekskresikan dalam feses, dan diasumsikan sudah diabsorbsi oleh ternak. Kecernaan suatu bahan merupakan pencerminan dari tinggi rendahnya manfaat 
bahan pakan tersebut. Kecernaan dipengaruhi oleh beberapa faktor yaitu: tingkat pemberian pakan, spesies hewan, suhu, laju perjalanan makanan melalui alat pencernaan, bentuk fisik bahan pakan, komposisi pakan, kandungan serat kasar bahan pakan, defisiensi zat makanan, pengolahan bahan pakan, pengaruh gabungan bahan pakan, dan gangguan saluran pencernaan meskipun tidak konsisten. Pengukuran nilai kecernaan pada dasarnya adalah suatu usaha untuk menentukan jumlah zat yang dapat diserap oleh saluran pencernaan, dengan mengukur jumlah pakan yang dikonsumsi dan jumlah pakan yang dikeluarkan melalui ekskreta. Berdasarkan uraian di atas, telah dilakukan penelitian untuk melihat sejauh mana pengaruh penggantian sebagian pakan ayam pedaging dengan tepung limbah labu kuning (Cucurbita moschata) terhadap nilai kecernaan bahan organik, serat kasar dan lemak kasar.

\section{MATERI DAN METODE PENELITIAN}

\section{Lokasi Dan Waktu Penelitian}

Penelitian ini dilaksanakan di Kandang Unggas, Fakultas Peternakan, Universitas Sam Ratulangi Manado. Kemudian dilanjutkan di laboratorium
Universitas Padjadjaran Bandung untuk analisa.

\section{Materi Penelitian}

Penelitian menggunakan 20 ekor ayam pedaging unsexed, strain CP 707 berumur 5 minggu dengan rataan berat badan \pm 1073 gram.

\section{Kandang dan Perlengkapan}

Kandang yang digunakan adalah kandang individu berukuran 20 × 30 × 30 $\mathrm{cm}^{3}$ sebanyak 20 unit yang dilengkapi dengan tempat makan dan minum. Perlengkapan lain yang digunakan adalah timbangan "Digital Ohaus" (untuk menimbang ayam, pakan dan ekskreta), wadah penampung ekskreta aluminium foil, pengaduk dan oven untuk mengeringkan ekskreta.

\section{Pakan Perlakuan}

Pakan yang digunakan terdiri dari jagung kuning, tepung ikan, tepung kedelai, dedak halus, bungkil kelapa, minyak, top mix dan limbah labu kuning. Komposisi zat nutrient dan energi bruto pakan basal dan tepung limbah labu kuning pada Tabel 1, dan komposisi zat nutrient dan energi bruto pakan perlakuan pada Tabel 2.

\section{Metode Penelitian}

\section{Rancangan Percobaan}

Penelitian ini merupakan penelitian eksperimental dengan menggunakan 
Tabel 1. Komposisi Zat Nutrient dan Energi Bruto Pakan Basal dan Tepung Limbah Labu Kuning.

\begin{tabular}{lcc}
\hline Zat Nutrient & Pakan Basal* & TLLK** \\
\hline Abu (\%) & 6,15 & 6,53 \\
Protein (\%) & 21,50 & 23,14 \\
Serat Kasar (\%) & 4,64 & 17,48 \\
Lemak (\%) & 12,94 & 14,59 \\
Beta-N & 54,77 & 38,26 \\
Energi Bruto (Kcal) & 3901,25 & 3882,40 \\
\hline
\end{tabular}

Keterangan : $\quad$ - TLLK = Tepung Limbah Labu Kuning

*) Hasil Analisis Laboratorium Nutrisi Ternak Ruminansia dan Kimia Makanan Ternak Fakultas Peternakan, Unpad, Bandung (2018).

**) Komalig et al., (2016)

Tabel 2. Komposisi Zat Nutrient dan Energi Bruto Pakan Perlakuan

\begin{tabular}{lcccc}
\hline Perlakuan & R0 & R1 & R2 & R3 \\
\hline Pakan Basal & 100 & 95 & 90 & 85 \\
Limbah Labu Kuning & 0 & 5 & 10 & 15 \\
\hline Zat Nutrient dan Energi Bruto & & & & \\
\hline Abu (\%) & 6,15 & 6,17 & 6,19 & 6,21 \\
Protein (\%) & 21,50 & 21,58 & 21,66 & 21,75 \\
Serat Kasar (\%) & 4,64 & 5,28 & 5,92 & 6,57 \\
Lemak (\%) & 12,94 & 13,02 & 13,11 & 13,19 \\
Beta-N & 54,77 & 53,94 & 53,12 & 52,29 \\
Energi Bruto (Kcal) & 3901,25 & 3900,31 & 3899,37 & 3898,42
\end{tabular}

Keterangan: Dihitung berdasarkan Tabel 1.

rancangan acak lengkap (Steel dan Torrie, 1995) yang terdiri dari 4 perlakuan dan 5 ulangan. Susunan perlakuan adalah sebagai berikut :

$\mathrm{R}_{0}=$ Pakan Basal 100\% (Tanpa Tepung Limbah Labu Kuning) $\mathrm{R}_{1}=$ Pakan Basal 95\% + Tepung Limbah Labu Kuning 5\%
$\mathrm{R}_{2}=$ Pakan Basal 90\% + Tepung Limbah

Labu Kuning 10\%

$\mathrm{R}_{3}=$ Pakan Basal 85\% + Tepung Limbah Labu Kuning 15\%

Data yang diperoleh dianalisis, dan bila terdapat perlakuan yang berbeda nyata dilanjutkan dengan uji Beda Nyata Jujur $(\mathrm{BNJ})$. 


\section{Variabel yang diukur}

Variabel yang diukur yaitu kecernaan bahan organik, kecernaan serat kasar dan kecernaan lemak kasar dihitung berdasarkan rumus (Tillman et al., 1998):

\section{Kecernaan Bahan Organik}

$$
\begin{aligned}
& \operatorname{KcBO}(\%)= \\
& \frac{\text { Konsumsi BO }- \text { BO ekskreta }}{\text { konsumsi } B O} \times 100
\end{aligned}
$$

\section{Kecernaan Serat Kasar (SK)}

$$
\begin{aligned}
& \operatorname{KcSK}(\%)= \\
& \frac{\text { konsumsi SK }- \text { SK ekskreta }}{\text { konsumsi SK }} \times 100
\end{aligned}
$$

\section{Kecernaan Lemak Kasar (LK)}

$$
\begin{aligned}
& \operatorname{KcLK}(\%)= \\
& \frac{\text { Konsumsi LK }- \text { LK ekskreta }}{\text { Konsumsi LK }} \times 100
\end{aligned}
$$

\section{Pengolahan tepung limbah labu kuning}

Pembuatan tepung limbah labu

kuning dapat dilihat pada Gambar 1.

berikut ini.

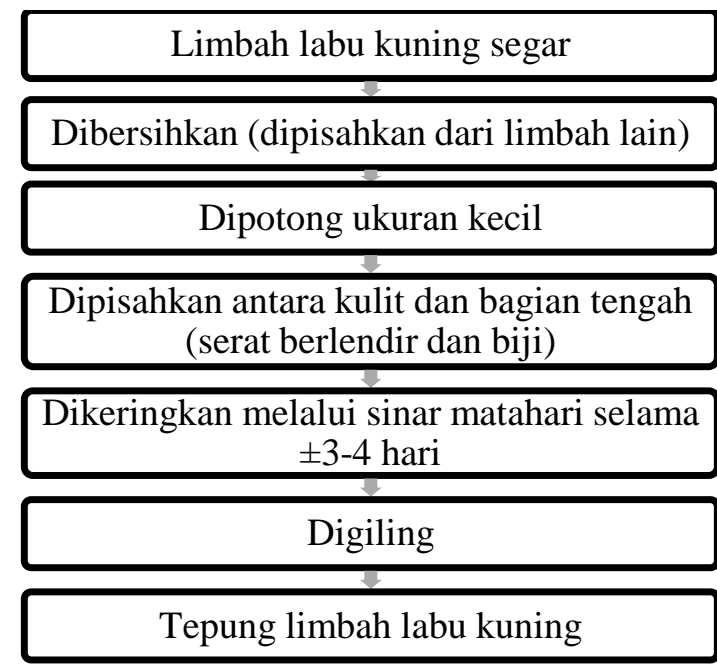

Gambar 1. Skema Pembuatan Tepung Limbah Labu Kuning

\section{Pengamatan}

Ternak percobaan ditempatkan secara acak dalam setiap unit kandang, tiap unit kandang berisi satu ekor ayam pedaging sehingga terdapat 20 unit kadang. Pada awal percobaan, ternak dipuasakan selama 24 jam sebelum perlakuan lebih lanjut. Selama penelitian pakan diberikan secara terbatas sebesar $80 \%$ dari jumlah konsumsi agar seluruh pakan terkonsumsi dan tidak ada sisa.

Ekskreta dikumpulkan sesuai
metode koleksi total dengan cara
menampung dan menimbang ekskreta
setiap hari selama 3 hari. Ekskreta
kemudian dikeringkan pada oven dengan
suhu $60^{\circ} \mathrm{C}$. Ekskreta yang dikeringkan
diambil sampel tiap perlakuan untuk
dianalisis kandungan bahan organik, serat
kasar dan lemak kasar.

\section{HASIL DAN PEMBAHASAN}

Rataan nilai kecernaan bahan organik, kecernaan serat kasar dan kecernaan lemak kasar ayam pedaging yang menggunakan tepung limbah labu kuning disajikan pada Tabel 3.

\section{Pengaruh Perlakuan Terhadap Nilai Kecernaan Bahan Organik}

Hasil penelitian kecernaan bahan organik pakan ayam pedaging yang diberi tepung limbah labu kuning (Cucurbita 
Tabel 3. Rataan Nilai Kecernaan Bahan Organik, Kecernaan Serat Kasar dan Kecernaan Lemak Kasar Pakan Ayam Pedaging yang Menggunakan Tepung Limbah Labu Kuning.

\begin{tabular}{lcccc}
\hline \multirow{2}{*}{ Parameter } & \multicolumn{4}{c}{ Perlakuan } \\
\cline { 2 - 5 } & R0 & R1 & R2 & R3 \\
\hline Bahan Organik (\%) & 79,39 & 83,56 & 82,48 & 80,82 \\
Serat Kasar (\%) & $56,92^{\mathrm{a}}$ & $63,10^{\mathrm{b}}$ & $67,71^{\mathrm{b}}$ & $66,30^{\mathrm{b}}$ \\
Lemak Kasar (\%1) & 78,74 & 78,24 & 77,56 & 76,06
\end{tabular}

Keterangan: Superskrip yang berbeda pada baris yang sama menunjukkan perbedaan yang sangat nyata $(\mathrm{P}<0,01)$.

moschata) dapat dilihat pada Tabel 3. Pada

Tabel 3, terlihat bahwa rataan nilai kecernaan bahan organik pada penelitian ini berkisar antara 79,39 - 83,56\%. Rataan nilai kecernaan bahan organik dalam penelitian ini lebih rendah dibandingkan dengan hasil penelitian Abun, et al. (2003) penentuan kecernaan pakan mengandung ampas umbi garut yang berkisar antara $84,03 \%-85,30 \%$ dan lebih tinggi dibandingkan dengan hasil penelitian Rahmayanti, et al. (2016) kecernaan bahan organik yang mengandung limbah tepung ikan gabus pasir 76,75\% - 78,41\%. Hasil Penelitian menunjukkan bahwa kecernaan bahan organik berturut-turut dari yang terendah diperoleh pada perlakuan R0 $(79,39 \%)$ selanjutnya diikuti oleh R3 $(80,82 \%)$, R2 (82,48\%) dan R1 $(83,56 \%)$.

Hasil penelitian ini menunjukkan bahwa pakan perlakuan tidak memberikan pengaruh yang nyata $(\mathrm{P}>0,05)$ terhadap kecernaan bahan organik. Hal ini membuktikan bahwa penggunaan tepung limbah labu kuning sampai $15 \%$ tidak menimbulkan efek negatif terhadap nilai kecernaan bahan organik. Sutardi (1980) melaporkan bahwa peningkatan kecernaan bahan organik sejalan dengan meningkatnya kecernaan bahan kering, karena sebagian besar komponen bahan kering terdiri atas bahan organik sehingga faktor-faktor yang mempengaruhi tinggi rendahnya kecernaan bahan kering akan berpengaruh juga terhadap tinggi rendahnya bahan organik. Kecernaan bahan organik dipengaruhi oleh kecernaan dari komponen bahan organik, yaitu protein, karbohidrat (BETN dan serat kasar) dan lemak. Guna mencapai daya cerna bahan organik yang optimal, nilai nutrien dari komponen bahan organik harus disesuaikan dengan kebutuhan ternak itu sendiri (Mangisah et al., 2006).

\section{Pengaruh Perlakuan Terhadap Nilai Kecernaan Serat Kasar}

Hasil penelitian kecernaan serat kasar pakan ayam pedaging yang diberi 
tepung limbah labu kuning (Cucurbita moschata) dapat dilihat pada Tabel 3. Pada Tabel 3, terlihat bahwa rataan nilai kecernaan serat kasar berkisar antara $56,92 \%-67,71 \%$. Persentase rataan nilai kecernaan serat kasar yang diperoleh pada penelitian ini tidak jauh berbeda dengan hasil penelitian Noferdiman et al. (2017) bahwa retensi serat kasar tepung Azolla (Azolla microphilla) hasil fermentasi yaitu $57,73 \%$ - 59,84\%. Hasil penelitian menunjukkan bahwa kecernaan serat kasar berturut-turut dari yang terendah diperoleh pada perlakuan R0 $(56,92 \%)$ selanjutnya diikuti oleh R1 (63,10\%), R3 (66,30\%) dan R2 $(67,71 \%)$. Hasil analisis keragaman memperlihatkan bahwa penggunaan tepung limbah labu kuning dalam pakan, memberikan pengaruh yang sangat nyata $(\mathrm{P}<0,01)$ terhadap kecernaan serat kasar. Hasil perbandingan rataan nilai kecernaan serat kasar melalui uji BNJ menunjukkan bahwa perlakuan R0 berbeda nyata lebih rendah dibandingkan dengan perlakuan $\mathrm{R} 1$, $\mathrm{R} 2$ dan R3 tetapi antara R1, R2 dan R3 tidak berbeda. Penelitian (Adrizal et al., 2011) melaporkan bahwa banyaknya pakan yang dikonsumsi belum menjamin peningkatan kecernaan zat makanan meskipun secara kuantitas kandungan zatzat makanan pakan sama. Selanjutnya menurut Noersidiq (2015) bahwa semakin meningkatnya konsumsi serat kasar semakin meningkat ekskresi serat kasar sehingga menurunkan kecernaan serat kasar. Hidanah et al. (2013) mengemukakan bahwa kecernaan serat kasar dipengaruhi oleh beberapa faktor antara lain konsumsi pakan, kadar serat dalam pakan, komposisi penyusun serat kasar dan aktivitas mikroorganisme. Kandungan serat kasar dalam pakan yang diberikan berpengaruh terhadap konsumsi pakan karena serat kasar memiliki sifat bulky (volumenous) yang terdiri dari selulosa, hemiselulosa dan lignin dimana sebagian besar sulit dicerna oleh unggas.

\section{Pengaruh Perlakuan Terhadap Nilai Kecernaan Lemak Kasar}

Hasil penelitian kecernaan lemak kasar pakan ayam pedaging yang diberi tepung limbah labu kuning (Cucurbita moschata) dapat dilihat pada Tabel 3. Pada Tabel 3, terlihat bahwa rataan nilai kecernaan lemak kasar pada penelitian ini berkisar antara 76,06\% - 78,74\%. Hasil penelitian Sukaryana et al. (2011) yang menyatakan bahwa pakan dengan campuran bungkil sawit dan dedak padi rata-rata adalah $66,33 \%-87,14 \%$. Hasil analisis keragaman menunjukkan bahwa pakan perlakuan tidak memberikan pengaruh yang nyata $(\mathrm{P}>0,05)$ terhadap kecernaan lemak kasar. Hal ini membuktikan bahwa penggunaan tepung limbah labu kuning sampai $15 \%$ tidak menimbulkan efek negatif terhadap nilai 
kecernaan lemak kasar. Secara angka menunjukkan bahwa kecernaan lemak kasar berturut-turut dari yang terendah diperoleh pada perlakuan R3 (76,06\%) selanjutnya diikuti oleh R2 $(77,56 \%)$, R1 $(78,24 \%)$ dan R0 (78,74\%). Hasil penelitian ini menunjukkan bahwa pakan perlakuan tidak memberikan pengaruh yang nyata $(\mathrm{P}>0,05)$ terhadap kecernaan lemak kasar. Hal tersebut terjadi karena kandungan serat kasar yang tinggi dalam pakan menyebabkan laju digesta meningkat dan serat kasar yang tidak tercerna akan membawa lemak yang tercerna keluar bersama ekskreta sehingga kecernaan lemak pada perlakuan relatif sama. Nilai kecernaan lemak ayam pedaging pada penelitian sejalan dengan penelitian Nurrohman (2015) yaitu berkisar antara $71,42 \%$ - 83,20\%. Lokapirnasari et al. (2015) menyatakan bahwa faktor yang dapat mempengaruhi kecernaan nutrisi lemak meliputi jenis ternak, komposisi pakan, jumlah konsumsi pakan, level pemberian pakan dan cara penyediaan pakan. Kecernaan lemak berkaitan dengan metabolisme yang terjadi pada ternak. Semakin tinggi persentase kecernaan lemak maka akan semakin baik metabolisme yang terjadi pada tubuh ternak.

\section{KESIMPULAN}

Tepung limbah labu kuning (Cucurbita moschata) dapat digunakan sebagai pengganti sebagian pakan ayam pedaging sampai $15 \%$ dilihat dari kecernaan bahan organik, serat kasar dan lemak kasar.

\section{DAFTAR PUSTAKA}

Abun, D. Rusmana dan N. P. Indriani. 2003. Penentuan kecernaan pakan mengandung ampas umbi garut (Maranta arundinacea Linn.) pada Ayam pedaging dengan Metode Pemotongan. Jurnal Bionatura Vol.5(3):227-238.

Adrizal, A., Y. Yusrizal, S. Fakhri, W. Haris, E. Ali. and C. Angel. 2011. Feeding native laying hens diets containing palm kernel meal with or without enzyme supplementations: 1. Feed conversion ratio and egg production. J. Appl. Poult. Res. 20: 40-49.

Badan Pusat Statistik, 2014. Data Produksi Tanaman Semusim. Jakarta.

Hidanah, S., E. M. Tamrin, D. S. Nazar dan E. Safitri. 2013. Limbah tempe dan limbah tempe fermentasi sebagai substitusi jagung terhadap daya cerna serat kasar dan bahan organik pada itik petelur. Jurnal Agroveteriner. 2 (1) : 71-79.

Komalig, D. F., J. R. Leke, J. Laihat, dan C. Sarajar. 2016. Penggunaan tepung limbah labu kuning dalam pakan terhadap penampilan produksi ayam ras petelur. Jurnal Zootek 36(2): 342-352 
Lokapirnasari, W.P., M.M. Fadli, R.T.S. Adikara dan Suherni. 2015. Suplementasi spirulina pada formula pakan mengandung bekatul fermentasi mikroba selulolitik terhadap kecernaan pakan. J. Agroveteriner. 3(2): 137-144.

Mangisah, I., Tristiarti, W. Murningsih, M.H. Nasoetion, E.S. Jayanti dan Y. Astuti. 2006. Kecernaan nutrien eceng gondok yang difermentasi dengan Aspergillus niger pada ayam broiler. J. Indon. Trop. Anim. Agric., 31(2): 124-128.

Noersidiq, A. 2015. Pengaruh Pemberian Tepung Kulit Nanas Yang Diberi Fermentasi Dengan Yoghurt Terhadap Retensi Bahan Kering, Protein Kasar dan Kecernaan Serat Kasar Pada Ayam Broiler Fase Awal. Skripsi. Fakultas Peternakan Universitas Jambi.

Noferdiman. N., Z. Zubaidah. dan S. Sestilawart. 2017. Retensi zat makanan pada ayam kampung yang mengkonsumsi pakan mengandung tepung azolla (Azolla microphilla) difermentasi dengan jamur pleurotus ostreatus. Jurnal IlmuIlmu Peternakan 20(1):39-50.

Nurrohman, A. 2015. Penggunaan Tepung Biji Alpukat dan Pengaruhnya Terhadap Kecernaan Lemak Kasar dan Energi Metabolis Pakan Ayam Broiler. Skripsi. Fakultas Peternakan dan Pertanian Universitas Diponegoro.

Rahmayanti. B., Tri. H. W., dan Sayed U. 2016. Kecernaan bahan kering, bahan organik dan protein kasar pakan yang mengandung tepung limbah ikan gabus pasir (Butis Amboinensis) sebagai substitusi tepung ikan pada broiler. Jurnal Peternakan Integratif 4(3):329-340.
Steel, R. G. D. dan J. H. Torrie. 1995 Prinsip dan Prosedur Statistika: Suatu Pendekatan Biometrik. Terjemahan B. Sumantri. Gramedia Pustaka Utama, Jakarta.

Sukaryana, Y., U. Atmomarsono, V. D. Yunianto, dan E. Supriyatna.2011. Peningkatan nilai kecernaan protein kasar dan lemak kasar produk fermentasi campuran bungkil inti sawit dan dedak padi pada broiler. JITP.1(3):167-172.

Sutardi, T. 1980. Landasan Ilmu Nutrisi Jilid 1. Departemen Ilmu Makanan Ternak. Fakultas Pertanian IPB. Bogor

Tillman, A. D., H. Hartadi, S. Reksohadiprodjo, S. Prawirokusumo dan S. Lebdosoekojo. 1998. Ilmu Makanan Ternak Dasar. Gadjah Mada University Press, Yogyakarta 